\title{
Publisher Correction: Mechanisms and impact of altered tumour mechanics
}

Hamid Mohammadi and Erik Sahai (D)

Correction to: Nature Cell Biology https://doi.org/10.1038/s41556-018-0131-2, published online 27 June 2018.

In the version of this Review originally published, owing to a technical error the text 'However, given the multitude' was incorrectly introduced after the sentence beginning 'The transition to a mesenchymal state is characterized.... This has now been amended in all online versions of the Review.

Published online: 10 July 2018

https://doi.org/10.1038/s41556-018-0163-7

\section{Publisher Correction: Early lineage segregation of multipotent embryonic mammary gland progenitors}

Aline Wuidart, Alejandro Sifrim, Marco Fioramonti, Shigeru Matsumura, Audrey Brisebarre, Daniel Brown, Alessia Centonze, Anne Dannau, Christine Dubois, Alexandra Van Keymeulen, Thierry Voet and Cédric Blanpain (D)

Correction to: Nature Cell Biology https://doi.org/10.1038/s41556-018-0095-2, published online 21 May 2018.

In the version of this Article originally published, ref. 52 was incorrectly only attributed to its corresponding author, Fre, S., and an older title was used. The correct citation should have been: Lilja, A. M. et al. Clonal analysis of Notch1-expressing cells reveals the existence of unipotent stem cells that retain long-term plasticity in the embryonic mammary gland. Nat. Cell Biol. https://doi.org/10.1038/s41556018-0108-1 (2018)'. This has now been amended in all online versions of the Article. 